\title{
Patterns of neoplastic recurrence in gastrectomized elderly patients
}

\author{
F Guida, A Antonino*, E Coppola Bottazzi, G Formisano, U Avallone, G Aprea, G Persico \\ From de Senectute: Age and Health Forum \\ Catanzaro, Italy. 5-7 December 2009
}

\section{Background}

The incidence of gastric cancer in elderly patients is increasing and the choice of treatment is controversial among physicians, oncologists and surgeons. In addition, about $2 / 3$ of patients present a neoplastic recurrence after a curative intervention [1]. The aim of this study is the analysis of the factors which influence the risk of recurrence in elderly patients.

\section{Materials and methods}

All patients who received a gastrectomy for adenocarcinoma in our surgical department from January 1998 to December 2002 were admitted to the study. Inclusion criteria were: a) Curative resection (R0); b)no metastases before surgery; c)no other primitive neoplasms; d)consensus of the patient for a follow-up of 5 years. Recurrence was indicated as haematogenous, peritoneal or locoregional on the basis of the first site of metastases. Patients were divided into two groups by age: cut-off was considered 70 years old.

\section{Results}

48 patients were admitted to the study : 26 male and 22 female patients, with a average age of 61,9 years old $(37-80) .16$ patients were $\geq 70$ years old.

During a 5-year follow-up we observed in the older group 9 recurrences $(56 \%)$ : in $44 \%$ cases there was a peritoneal recurrence, in $33 \%$ a haematogenous recurrence and in $23 \%$ of patients a locoregional disease. In patients $<70$ years old we observed a peritoneal recurrence only in $5 \%$ of cases. (Table 1 ).

Factors correlated with a neoplastic recurrence in the older group were: pTNM III at diagnosis (78\% vs $43 \%$ ), subtotal gastrectomy ( $65 \%$ vs $56 \%$ ), Lauren diffuse

Department of General and Geriatric Surgery and Diagnostic and Operative Endoscopy, University of Naples "Federico II", Italy adenocarcinoma (45\% vs $33 \%$ ) and a Linfonodal ratio $($ LNR) $\geq 20 \%$ (89\% vs 30\%).(Table 2$)$

\section{Conclusions}

In elderly patients we observed a neoplastic recurrence in $56 \%$ of cases: first site of disease was peritoneum (44\% ) then haematogenous recurrence (33\%).In younger patients, instead, a locoregional recurrence was more frequent (62\% vs $23 \%$ ). Predictive factors of neoplastic recurrence in elderly patients were: pTNM III, subtotal gastrectomy, Lauren diffuse adenocarcinoma and a LNR $\geq 20 \%$. These factors can help the surgeon and the oncologist to identify, in a population of elderly

Table 1 Recurrence site for age

\begin{tabular}{ccc}
\hline $\begin{array}{c}\text { RECURRENCE } \\
\text { SITE }\end{array}$ & $\begin{array}{c}\geq \mathbf{7 0} \text { YEARS (\%) }-\mathbf{9} \\
\text { patients }\end{array}$ & $\begin{array}{c}<\mathbf{7 0} \text { YEARS (\%) - 18 } \\
\text { patients }\end{array}$ \\
\hline Peritoneal & $4(44 \%)$ & $1(5 \%)$ \\
Haematogenous & $3(33 \%)$ & $6(33 \%)$ \\
Local & $2(23 \%)$ & $11(62 \%)$ \\
\hline
\end{tabular}

Table 2 Factors associated with recurrence in patients $\geq 70$ years

\begin{tabular}{|c|c|c|}
\hline & $\begin{array}{c}\text { Neoplastic recurrence }+ \\
(\%)\end{array}$ & $\begin{array}{c}\text { Neoplastic recurrence - } \\
(\%)\end{array}$ \\
\hline Patients & $9(56 \%)$ & $7(44 \%)$ \\
\hline MaleFemale & $6(65 \%) 3(35 \%)$ & $5(70 \%) 2(30 \%)$ \\
\hline $\begin{array}{l}\text { pTNM I } \\
\text { PTNM II } \\
\text { pTNM III }\end{array}$ & $1(11 \%) 1(11 \%) 7(78 \%)$ & $1(14 \%) 3(43 \%) 3(43 \%)$ \\
\hline $\begin{array}{c}\text { Total gastrectomy } \\
\text { Subtotal } \\
\text { gastrectomy }\end{array}$ & $3(35 \%) 6(65 \%)$ & $3(44 \%) 4(56 \%)$ \\
\hline $\begin{array}{l}\text { Intestinal } \\
\text { Diffuse }\end{array}$ & $5(55 \%) 4(45 \%)$ & $4(67 \%) 3(33 \%)$ \\
\hline $\begin{array}{l}L N R<20 \% \\
L N R \geq 20 \%\end{array}$ & 1 (11\%)8 (89\%) & $5(70 \%) 2(30 \%)$ \\
\hline
\end{tabular}


gastrectomized patients, who needs a closer follow-up due to a higher risk of recurrence, in order to permit a more aggressive therapy.

Published: 19 May 2010

\section{Reference}

1. Whiting J, Sano T, Saka M, Fukagawa T, Katai H, Sasako M: Follow-up of gastric cancer: a review. Gastric Cancer. 2006, 9:74-81.

doi:10.1186/1471-2318-10-S1-A10

Cite this article as: Guida et al: Patterns of neoplastic recurrence in gastrectomized elderly patients. BMC Geriatrics 2010 10(Suppl 1):A10.

Submit your next manuscript to BioMed Central and take full advantage of:

- Convenient online submission

- Thorough peer review

- No space constraints or color figure charges

- Immediate publication on acceptance

- Inclusion in PubMed, CAS, Scopus and Google Scholar

- Research which is freely available for redistribution

Submit your manuscript at www.biomedcentral.com/submit 